\title{
Peningkatan Kemampuan Guru dalam Melaksanakan Pendekatan Seru melalui Tindakan Tindak Lanjut Supervisi Kunjungan Kelas oleh Kepala Sekolah
}

\author{
Sugiarti \\ Sekolah Dasar Negeri 84 Singkawang \\ E-mail:sugiarti84@gmail.com
}

\begin{abstract}
Abstrak. Penelitian kegiatan supervisi ini dilakukan oleh Kepala Sekolah agar dapat memperbaiki atau meningkatkan kualitas dari pembelajaran SERU yang telah diterapkan oleh guru-guru SDN 84 Singkawang. Prosedur penelitian dilaksanakan dengan menggunakan siklus-siklus tindakan (daur ulang) yang meliputi perencanaan (Planning), tindakan (Action), mengobservasi (Observation), dan melakukan refleksi (Reflection). Penelitian Tindakan Sekolah (PTS) ini dilakukan di SD Negeri 84 Singkawang, Kecamatan Singkawang Utara Kota Singkawang pada semester II Tahun pelajaran 2016-2017. Hasil supervisi keterampilan guru dalam penerapan pendekatan pembelajaran SERUsiklus 1 masih kurang dan mengalami peningkatan pada siklus 2. Data hasil penilaian RPP juga mengalami peningkatan. Dilihat dari dari segi siswa terlihat adanya peningkatan parrtisipasi siswa dalam kegiatan belajar mengajar. Data hasil observasi menunjukkan bahwa aktivitas siswa dalam kelas 1mencapai rata-rata skor 5,79 (cukup), dalam kelas 2 mencapai (cukup). Kelas 3 mencapai skor rata-rata 7,12 (baik), kelas 4 mencapai 7,30 (baik), dan kelas 5 mencapai 7,44 (Baik). Hal tersebut menunjukkan bahwa aktivitas siswa telah mengalami peningkatan namun belum mencapai katagori baik sehingga perlu ditingkatkan.
\end{abstract}

Kata Kunci: Pendekatan SERU; Supervisi; Kunjungan Kelas

\section{PENDAHULUAN}

Perkembangan masyarakat manusia makin maju dengan ditemukannya sains dan teknologi oleh manusia untuk menjawab segala permasalahan kehidupan yang dihadapinya [1]. Pendidikan merupakan sebuah sistem yang terbentuk dari berbagai sub sistem yang sinergis dalam proses kegiatan untuk mencapai tujuan yang di harapkan.Aktifitas yang harus di lakukan oleh seorang guru adalah mengajar,mendidik dan melatih. Keberhasilan pendidikan sudah barang tentu harus dilandasi oleh keberhasilan proses pembelajaran. Kegiatan pembelajaran dapat dikatakan berhasil apabila siswa sebagai peserta didik dapat menguasai kompetensi yang sudah ditargetkan.

Keberhasilan pembelajaran ditentukan oleh berbagai faktor, diantara perencanaan pembelajaran sebagai rancangan target, proses dan penilaian pembelajaran. Untuk mencapai hasil yang optimal tujuan pembelajaran harus dirumuskan sedemikian rupa yang dikemas di dalam RPP (Rencana pelaksanaan pembelajaran) [2]. RPP merupakan hal yang sangat penting dalam pelaksanaan pembelajaran karena untuk rencana yang baik maka mustahil akan di hasilkan keluaran (output) yang baik. Dalam rencana pelaksanaan pembelajaran SERU yang memuat komponen: (1) Senang, yang ditandai siswa belajar tidak terpaksa, merasa tertarik,konsentrasi,terlibat aktif, (2) Efektif,yang ditunjukkan oleh perubahan sikap, spritual, sosial, keterampilan,pengetahuan,karakter harmoni hijau pengalaman berharga dan bermakna, (3) Ramah, yang diwujudkan dengan pengelolaan pembelajaran tangtidak diskriminasi, menyambut kehadiran siswa,penghargaan dan motivasi,penggunaan alam dan barang bekas,partisipasi penataan ruang kelas, dan (4) Unik dengan memanfaatkan kearifan lokan seperti: permainan tradisional seni dan budaya lokal.

Pembelajaran SERU merupakan suatu proses pembelajaran, dimana guru harus menciptakan suasana sedemiakian rupa sehingga siswa aktif dan berani untuk mengemukaakan gagasan. Belajar memang merupakan suatu proses aktif dari si pembelajar dalam membangun pengetahuannya, bukan proses pasif yang hanya menerima kucuran ceramah guru tentang pengetahuan. Jika pembelajaran tidak memberikan kesempatan kepada siswa untuk berperan aktif, maka pembelajaran tersebut bertentangan dengan hakikat belajar. Peran aktif dari siswa sangat penting dalam rangka pembentukan generasi yang kreatif, yang mampu menghasilkan sesuatu untuk kepentingan dirinya dan orang lain.

Melalui penerapan pembelajaran SERU siswa didik untuk gemar membaca, belajar dengan sungguh-sungguh, 
mengerjakan sesuatu pekerjaan dengan sebaik mungkin, berupaya mendapatkan hasil terbaik, bekerjasama dengan sesama teman dan hal-hal positif lainnya, yang semuanya memiliki keterkaitan dengan indikator nilai-nilai pembangunan karakter bangsa.Pembelajaran harus dibangun dalam suasana senang, gembira, dan disesuaikan dengan karakteristik lingkungan serta kebutuhan siswa.

Dalam pelaksanaan Pembelajaran SERU di SDN 84 Singkawang, terdapat alur atau proses yang dimulai dengan mewujudkan suasana senang dalam belajar misalnya sebelum pembelajaran dimulai siswa diajak untuk beryel-yel harmoni (harmoni diri,harmoni sesama, dan harmoni alam). Selanjutnya dalam pelaksanaan pembelajaran siswa diajak dikondisikan belajar secara kontekstual yaitu belajar di lingkungan sekolah atau di luar ruangan kelas dan dalam penilaian pembelajaran siswa dinilai selama berjalannya proses pembelajaran dan hasil belajar yang diperoleh siswa.

Salah satu alternatif yang mendorong keaktifan siswa dalam pembelajaran adalah pendekatan pembelajaran SERU (Senang, Efektif, Ramah, dan Unik )sebagai perolehan pembelajaran yang terdapat pada Sekolah Harmoni. Salah satu alternatif mendorong keaktifan siswa dalam pembelajaran adalah penyebaran pembelajaran SERU (Senang, Efektif, Ramah, dan Unik) sebagai perolehan pembelajaran yang terdapat pada Sekolah Harmoni Salah satu alternatif mendorong keaktifan siswa dalam pembelajaran adalah penyebaran pembelajaran SERU (Senang, Efektif, Ramah, dan Unik) sebagai perolehan pembelajaran yang terdapat pada Sekolah Harmoni Hijau.

Di SDN 84 Kota Singkawang sebenarnya sudah menerapkan konsep pembelajaran SERU. Hal ini dapat dilihat pada RPP guru yang mengajar (terlampir), dalam proses pembelajaran telah diterapkan pembelajaran SERU yang tampak pada bagian kegiatan awal, hingga kegiatan penutup pembelajaran.

Pembelajaran SERU di SDN 84 sudah diterapkan dari kelas I hingga kelas VI. Hanya saja, dalam pelaksanaannya, pembelajaran SERU ini belum diterapkan secara maksimal. Dalam kegiatan observasi yang dilakukan, perencanaan pembelajaran SERU sudah ada di dalam RPP, hanya saja tidak terlalu dikembangkan di dalam kelas. Pelasanaan dalam pembelajaran lebih sering menggunakan metode klasik, walaupun di dalam RPP menggunakan pembelajaran SERU. Di dalam proses penilaian, hanya sebagian guru saja yang sudah menerapkan pembelajaran SERU ke dalam sistem penilaiannya.

\section{Pelaksanaan Pembelajaran SERU}

Pembelajaran SERU dirancang dengan tujuan untuk lebih mengaktifkan anak, mengembangkan kreativitas sehingga efektif namun tetap menyenangkan dan berorientasi pada kondisi lingkungan sekolah. Pembelajaran SERU sesungguhnya adalah pendekatan pembelajaran yang memuat empat komponen utama sebagai ciri pembelajaran yaitu pembelajaran yang menyenangkan (Senang), pembelajaran yang bermakna (Efektif), pembelajaran yang adil, akrab, dan nyaman (Ramah) dan pembelajaran berdasarkan kearifan lokal (Unik) [3].
Gambaran pembelajaran SERU diperlihatkan dengan berbagai kegiatan yang terjadi selama KBM. Pada saat yang sama, gambaran tersebut menunjukkan kemampuan yang perlu dikuasai guru untuk menciptakan keadaan tersebut. Berikut adalah beberapa contoh dalam kegiatan pembelajaran dan kemampuan guru yang sesuai dengan karakteristik dan kebutuhan pembelajaran. Kemampuan guru dalam merancang dan mengelola pembelajaran yang untuk mendorong siswa berperan aktif dalam pembelajaran misalnya melalui percobaan, diskusi kelompok, memecahkan masalah, mencari informasi, menulis laporan/puisi/cerita, berkunjung ke luar kelas.

Selain itu guru juga memberikan kesempatan kepada siswa untuk mengembangkan keterampilan dalam melakukan percobaan, pengamatan atau wawancara serta menulis laporan/hasil karya lain dengan kata-kata sendiri. Hasil dari pembelajaran dapat dilihat melalui penilaian dan kemajuan siswa secara terus menerus dengan selalu memantau kerja siswa dan memberikan umpan balik.

\section{Supervisi Kunjungan Kelas}

Secara sematik, Supervisi pendidikan adalah pembinaan yang berupa bimbingan atau tuntunan ke arah perbaikan situasi pendidikan pada umumnya dan peningkatan mutu mengajar dan belajar pada khususnya. Dan Supervisi Juga merupakan kegiatan pembinaan yang dilakukan kepala sekolah kepada guru untuk membantu memperbaiki situasi pembelajaran agar para siswa dapat belajar lebih efektif dengan prestasi belajar yang meningkat. Supervisi kunjungan kelas adalah salah satu teknik supervisi yang dilakukan kepala sekolah dengan cara mengunjungi kelas untuk mengamati secara langsung bagaimana performa guru dalam pembelajaran serta membantu meningkatkan proses pembelajaran sehingga hasil belajar siswa semakin baik. Teknik Individual merupakan teknik pelaksanaan supervisi yangdigunakan supervisor kepada pribadi-pribadi guru guna peningkatan kualitas pengajaran disekolah [4]. Teknik-teknik individual dalam pelaksanaan supervisi yaitu teknik kunjungan kelas dan teknik observasi kelas.

\section{Langkah-langkah Pelaksanaan Tindak Lanjut Suvervisi Kunjungan Kelas}

Sepervisi merupakan kegiatan supervisor yang dilakukan untuk perbaikan proses belajar mengajar [5]. Supervisi pada intinya adalah supervisi akademis dimana langah-langah yang dilakukan adalah merencanakan program supervisi akademik dalam rangka peningkatan profesionalisme guru, melaksanakan supervisi akademik terhadap guru dengan menggunaan penedekatan dan teknik supervisi yang tepat, serta menindak lanjuti hasil supervisi akademik terhadap guru dalam rangka peningkatan profesionalismenya.

Secara umum, ditemukan beberapa kelemahan yang perlu diperbaiki bagi seorang guru dalam peningkatan kualitas pembelajaran sekaligus peningkatan profesionalisme guru, seperti: pengembangan indikator dan materi pembelajaran, penggunaan metode pembelajaran yang belum variatif, lemahnya penguasaan guru dalam midel-model pembelajaran aktif. 
Dikarenakan hal tersebut, maka perlu adanya Perencanaan Supervisi Akademik yang dilakukan setiap awal semester dan akhir semester. Kegiatan ini dilaksanakan oleh Kepala Sekolah bersama dengan Pegawas Pembina [6]. Dalam pelaksanaannya, Supervisi Akademik perlu dirancang, diorganisasikan, direalisasikan, dan dilakukan pengawasan [7]. Perencanaan Supervisi Akademik dapat dibuat berupa dokumen yang berikutnya dijadikan pedoman oleh Kepala Sekolah dalam melaksanakan program supervisi guna mengembangkan kemampuan guru dalam mengelola program pembelajaran dan tercapainya tujuan dari pembelajaran.

Dalam prosesnya, pelaksanaan supervisi dapat dilakukan dengan 2 cara, yakni:

1. Pendekatan Langsung

Pendekatan langsung dilakukan oleh Kepala Sekolah kepada guru dengan cara komunikasi langsung dalam membantu pemecahan masalah-masalah dalam proses pembelajaran.

2. Pendekatan Tidak Langsung

Pendekatan Tidak Langsung dilakukan oleh Kepala Sekolah atau Supervisor kepada guru untuk memecahkan masalah-masalah dalam proses pembelajaran melalui pihak lain, seperti: MGMP, Pelatihan dalam jabatan, Konsultan, dan Pengawas.

Setelah pelaksanaan Supervisi dan analisis hasil dari kegiatan supervisi, maka langkah berikutnya adalah tindak lanjut. Tindak lanjut dapat berupa pemberian penguatan dan penghargaan, teguran, maupun memberikan kesempatan untuk mengikuti pelatihan yang bertujuan untuk meningkatkan kualitas guru tersebut.

Langkah-langkah yang perlu dilaksanakan dalam tindak lanjut supervisi kunjungan kelas adalah sebagai berikut:

1. Mengkaji rangkuman hasil penilaian.

2. Apabila ternyata tujuan supervisi akademik dan standar-standar pembelajaran belum tercapai, maka sebaiknya dilakukan penilaian ulang terhadap pengetahuan, keterampilan dan sikap guru yang menjadi tujuan pembinaan.

3. Apabila ternyata memang tujuannya belum tercapai maka mulailah merancang kembali program supervisi akademik guru untuk masa berikutnya.

4. Membuat rencana aksi supervisi akademik berikutnya.sebagai tindak lanjut

Oleh karena itu, diperlukan kegiatan supervisi yang dilakukan oleh Kepala Sekolah agar dapat memperbaiki atau meningkatkan kualitas dari pembelajaran SERU yang telah diterapkan oleh guru-guru SDN 84 Singkawang.

\section{METODE PENELITIAN}

Penelitian ini menggunakan pendekatan kualitatif dengan jenis penelitian tindakan kelas dengan menggunakan siklussiklus tindakan (daur ulang). Siklus di dalam tindakan di awali dengan perencanaan (Planning), tindakan (Action), mengobservasi (Observation), dan melakukan refleksi (Reflection) [8]. Siklus ini terus dilakukan hingga peningkatan yang diharapkan tercapai.
Prosedur pelaksanaan tindakan kelas yang dilakukan dalam penelitian ini dapat dilihat seperti dalam bagan berikut ini:

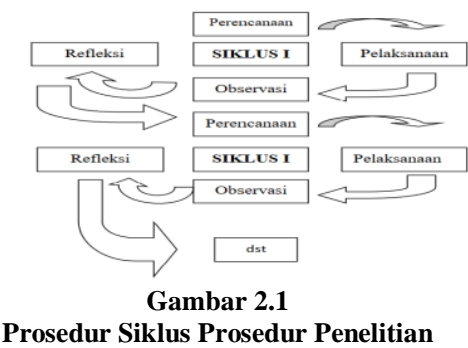

Penelitian Tindakan Sekolah (PTS) ini dilakukan di SD Negeri 84 Singkawang, Kecamatan Singkawang Utara Kota Singkawang pada semester II Tahun pelajaran 2016-2017. Waktu Penelitian dari bulan Januari sampai dengan Mei 2017. Teknik pengumpulan data dalam penelitian ini diperoleh melalui observasi dan catatan data lapangan, wawancara, catatan hasil refleksi/diskusi yang dilakukan oleh peneliti dan subjek penelitian. Penentuan teknik tersebut didasarkan ketersediaan sarana dan prasana dan kemampuan yang dimiliki peneliti dan subjek penelitian.

Kegiatan analisis data akan dilakukan dengan melakukan catatan refleksi, yakni pemikiran yang timbul pada saat mengamati dan merupakan hasil proses membandingkan, mengkaitkan atau menghubungkan data yang ditampilkan dengan data sebelumnya atau dengan teori-teori yang relevan [9].

Pembelajaran dalam menerapkan pendekatan Pembelajaran SERU dalam penelitian ini dikatakan berhasil jika mencapai nilai ketuntasan atau lebih. Indikator yang digunakan untuk mengukur peningkatan keaktifan siswa adalah peningkatan keaktifan siswa baik secara individual maupun klasikal serta aktivitas siswa menjawab maupun mengajukan pertanyaan, interaksi antar siswa ketika siswa melakukan diskusi, dalam kegiatan diskusi dicatat keterlibatan masing-masing siswa dalam kelompok, ketepatan waktu siswa dalam menyelesaikan tugas.

\section{HASIL DAN PEMBAHASAN}

\section{Hasil Penelitian}

Tabel 3.1

Penilaian RPP Siklus 1

\begin{tabular}{llccc}
\hline No & Nama Guru & Kelas & Skor & Keterangan \\
\hline 1 & Mulyati, S.Pd.SD & I & 40 & Kurang \\
2 & Rumisnah & II & 60 & Cukup \\
3 & Nazilah, S.Pd.SD & III & 63 & Cukup \\
4 & Juparmi, S.Pd & IV & 60 & Cukup \\
5 & Semiwati, S.Pd.SD & V & 50 & Kurang \\
\hline \multicolumn{2}{l}{ Keterangan: }
\end{tabular}

$\begin{array}{ll}\text { Keterangan: } & \\ \text { Pedoman Penafsiran Skor } \\ 86 \%-100 \% & \text { : Baik Sekali } \\ 70 \%-85 \% & \text { : Baik } \\ 55 \%-69 \% & \text { : Cukup } \\ <55 \% \text { : Kurang } & \end{array}$

Berdasarkan pendoman penskoran di atas dapat dinyatakan bahwa kelima RPP yang telah dibuat oleh guru yang menjadi subyek penelitian masih dikatagorikan kurang baik. Sedangkan dilihat dari parktek atau pelaksanaan 
pembelajarannya, juga terlihat bahwa kegiatan pembelajaran yang dilakukan kelima guru tersebut belum sesuai dengan yang diharapkan. Hal ini tampak dari data hasil observasi seperti tampak pada tabel berikut ini.

Tabel 3.2

Penilaian Kegiatan Pembelajaran

\begin{tabular}{llccc}
\hline No & \multicolumn{1}{c}{ Nama Guru } & Kelas & Nilai & Keterangan \\
\hline 1 & Mulyati, S.Pd.SD & I & 51 & Kurang \\
2 & Rumisnah & II & 63 & Cukup \\
3 & Nazilah, S.Pd.SD & III & 69 & Cukup \\
4 & Juparmi, S.Pd & IV & 68 & Cukup \\
5 & Semiwati, S.Pd.SD & V & 57 & Cukup \\
\hline
\end{tabular}

Berdasarkan tabel di atas dan dengan berpedoman pada penafsiran skor tersebut, terlihat bahwa pelaksanaan pembelajaran yang dilakukan oleh kelima orang guru yang menjadi subyek penelitian hanya masuk pada kategori cukup. Berdasarkan ketentuan tersebut aktivitas siswa dalam kegiatan belajar mencapai skor rata-rata 5,79 (cukup), dengan rincian: a) tingkat keseriusan dalam mengikuti pelajaran mendapatkan mendapat nilai rata-rata 2,55 (cukup, mendekati baik); b) mengajukan atau menjawab pertanyaan mendapatkan nilai rata-rata 1,41 (kurang) dan c) keterlibatan dalam kerja kelompok atau diskusi mencapai nilai rata-rata 1,83 (mendekati cukup).

Sedangkan untuk kelas 2, aktivitas siswa dalam pembelajaran pada siklus 1 ini juga masih kurang baik hal ini karena skor yang diperoleh baru mencapai 5,59 (cukup) dengan rincian: a) tingkat keseriusan dalam mengikuti pelajaran mendapatkan mendapat nilai rata-rata 2,31 (cukup); b) mengajukan atau menjawab pertanyaan mendapatkan nilai rata-rata 1,38 (kurang) dan c) keterlibatan dalam kerja kelompok atau diskusi mencapai nilai rata-rata 1,90 (kurang).

Kelas 3 pada siklus 1 ini masih belum baik hal ini karena skor rata-rata yang diperoleh baru mencapai 5,33 (cukup) dengan rincian: a) tingkat keseriusan dalam mengikuti pelajaran mendapatkan mendapat nilai rata-rata 2,36 (cukup); b) mengajukan atau menjawab pertanyaan mendapatkan nilai rata-rata 1,31 (kurang); dan c) keterlibatan dalam kerja kelompok atau diskusi mencapai nilai rata-rata 1,67 (mendekati cukup).

Selanjutnya, kelas 4 pada siklus 1 ini masih belum baik hal ini karena skor rata-rata yang diperoleh baru mencapai 5,33 (cukup) dengan rincian: a) tingkat keseriusan dalam mengikuti pelajaran mendapatkan mendapat nilai rata-rata 2,36 (cukup); b) mengajukan atau menjawab pertanyaan mendapatkan nilai rata-rata 1,31 (kurang); dan c) keterlibatan dalam kerja kelompok atau diskusi mencapai nilai rata-rata 1,67 (mendekati cukup).

Berikutnya, kelas 5 pada siklus 1 ini masih belum baik hal ini karena skor rata-rata yang diperoleh baru mencapai 5,33 (cukup) dengan rincian: a) tingkat keseriusan dalam mengikuti pelajaran mendapatkan mendapat nilai rata-rata 2,36 (cukup); b) mengajukan atau menjawab pertanyaan mendapatkan nilai rata-rata 1,31 (kurang); dan c) keterlibatan dalam kerja kelompok atau diskusi mencapai nilai rata-rata 1,67 (mendekati cukup).

Hasil refleksi berupa kegiatan diskusi antara peneliti dan mitra peneliti diketahui bahwa adanya kekurangan baik dilihat dari perencanaan pembelajaran yang dibuat, pelaksanaan pembelajaran dan keaktifan siswa pada umumnya disebabkan karena metode yang digunakan masih belum variatif dan kurang menyenangkan. Guru-guru tersebut belum mampu memaknai pendekatan Pembelajara SERU dengan sebenarnya

Tabel 3.3 Penilaian RPP Siklus 2

\begin{tabular}{llccc}
\hline No & Nama Guru & Kelas & Skor & Keterangan \\
\hline 1 & Mulyati, S.Pd.SD & I & 37,5 & Kurang \\
2 & Rumisnah & II & 60 & Cukup \\
3 & Nazilah, S.Pd.SD & III & 83 & Baik \\
4 & Juparmi, S.Pd & IV & 60 & Cukup \\
5 & Semiwati, S.Pd.SD & V & 80 & Baik \\
\hline
\end{tabular}

Berdasarkan pendoman penskoran di atas dapat dinyatakan bahwa RPP yang telah dibuat guru kelas 1 dapat dikatagorikan masih kurang baik, sedangkan RPP yang dibuat guru kelas 2, kelas 3, kelas 4 dan kelas 5 dapat dikatagorikan baik. Beberapa permasalahan yang muncul berdasarkan hasil refleksi (diskusi antara peneliti dan mitra peneliti) yang selanjutnya menjadi bahan perbaikan untuk siklus berikutnya.Sedangkan dilihat dari parktek atau pelaksanaan pembelajarannya, juga terlihat bahwa kegiatan pembelajaran yang dilakukan kelima guru tersebut belum sesuai dengan yang diharapkan. Hal ini tampak dari data hasil observasi seperti tampak pada tabel berikut ini.

Tabel 3.4

Penilaian Kegiatan Pembelajaran

\begin{tabular}{llccc}
\hline No & \multicolumn{1}{c}{ Nama Guru } & Kelas & Nilai & Keterangan \\
\hline 1 & Mulyati, S.Pd.SD & I & $54 \%$ & Kurang \\
2 & Rumisnah & II & $66 \%$ & Cukup \\
3 & Nazilah, S.Pd.SD & III & $77 \%$ & Baik \\
4 & Juparmi, S.Pd & IV & $73 \%$ & Baik \\
5 & Semiwati, S.Pd.SD & V & $72 \%$ & Baik \\
\hline
\end{tabular}

Berdasarkan tabel di atas dan dengan berpedoman pada penafsiran skor tersebut, terlihat bahwa pelaksanaan pembelajaran yang dilakukan oleh kelima orang guru yang menjadi subyek penelitian hanya masuk pada kategori cukup.Berdasarkan tabel di atas dan dengan berpedoman pada penafsiran skor tersebut, terlihat bahwa pelaksanaan pembelajaran yang dilakukan oleh oleh guru kelas 1 masih dikatagorikan kurang baik. Sedangkan untuk guru kela 2,3,4,5 dapat dikatagorikan baik, walau terdapat beberapa unsur penilaian yang masih kurang baik.

Berdasarkan rumus tersebut diperoleh data aktivitas siswa dalam kelas1 aktivitas siswa dalam KBM pada siklus 1 ini juga masih kurang baik hal ini karena skor yang diperoleh baru mencapai 5,79 (cukup) dengan rincian: a) tingkat keseriusan dalam mengikuti pelajaran mendapatkan mendapat nilai rata-rata 2, 50 (cukup, mendekati baik); b) mengajukan atau menjawab pertanyaan mendapatkan nilai rata-rata 1,90 (mendekati cukup) dan c) keterlibatan dalam kerja kelompok atau diskusi mencapai nilai rata-rata 1,39 (cukup).

Sedangkan untuk kelas 2 pada siklus 1 ini masih belum baik hal ini karena skor rata-rata yang diperoleh baru mencapai 5,59 (cukup) dengan rincian: a) tingkat keseriusan dalam mengikuti pelajaran mendapatkan mendapat nilai ratarata 2,55 (cukup, dan mendekati baik); b) mengajukan atau menjawab pertanyaan mendapatkan nilai rata-rata 1,41 
(mendekati cukup); dan c) keterlibatan dalam kerja kelompok atau diskusi mencapai nilai rata-rata 1,83 (mendekati cukup).

Di kelas 3 aktivitas siswa dalam kegiatan belajar agak lebih tinggi yakni mencapai skor 5,33 (cukup, mendekati baik) namun masih harus ditingkatkan. Berdasarkan hasil refleksi tersebut, pada siklus berikutnya akan ditampilkan media pembelajaran yang lebih menarik dan variatif serta dapat merangsang atau memotivasi siswa untuk terlibat secara aktif. Berdasarkan hasil refleksi siklus 1, dam 2 yang mencoba mengungkapkan keberhasilan maupun ketidakberhasilan kegiatan bimbingan yang dilakukan kepala sekolah terhadap guru-guru SDN 84 Singkawangdalam penerapan pendekatan pembelajaran SERU dapat disimpulkan bahwa pemahaman dan keterampilan guru-guru SDN 84 Singkawang tentang pembelajaran SERU mulai meningkat. Oleh karena itu, kegiatan Penelitian Tindakan Sekolah (PTS) tentang Upaya Mewujudkan Pendidikan Karakter Bangsa Melalui Penerapan Pendekatan Pembelajaran Senang, Efektif, Ramah, dan Unik (SERU) Dalam pembelajaran Di SDN 84 dianggap selesai.

\section{Pembahasan}

Berikut penulis uraikan pembahasan data penelitian siklus demi siklus penelitian.

\section{Pembahasan Data Siklus 1}

Tujuan yang ingin dicapai dalam PTS ini adalah a) Meningkatkan pemahaman Guru SDN 84 Singkawang dalam mengembangkan pembelajaran SERU; b) Meningkatkan keterampilan Guru SDN 84 Singkawang dalam mengembangkan pembelajaran SERU. Hasil analisis siklus 1 menunjukkan bahwa:

a.Dilihat dari aspek guru, tampak bahwa pada siklus 1 ini keterampilan guru dalam penerapan pendekatan pembelajaran SERUmasih kurang. Ini terlihat dari masih kurangnya keterampilan guru dalam menentukan atau memilih metode dan media yang variatif dan dapat merangsang aktivitas siswa.

b.Data hasil penilaian RPP pada siklus 1 menunjukkan bahwa pencapaian skor nilai RPP guru kelas 1 adalah 40\%; guru kelas 2 memperoleh skor $60 \%$; guru kelas 3 memperoleh skor $63 \%$; guru kelas 4 memperoleh skor 60\%; guru kelas 5 memperoleh skor $50 \%$. Dengan demikian kelima RPP tersebut masih dikatagorikan kurang baik.

c.Sedangkan berdasarkan data hasil observasi pelaksanaan KBM menunjukkan pencapaian nilai pelaksanaan pembelajaran kelas 1 adalah 51\%; kelas 2 memperoleh skor 63\%,guru kelas 3 memperoleh skor $69 \%$, guru kelas 4 memperoleh skor $68 \%$, guru kelas 5 memperoleh skor $57 \%$. Dengan demikian kelima pelaksanaan pembelajaran tersebut masih dikatagorikan kurang baik.

d.Dilihat dari dari aspek siswa, terlihat belum adanya peningkatan partisipasi siswa dalam kegiatan belajar mengajar. Berdasarkan data hasil observasi menunjukkan bahwa aktivitas siswa pada siklus 1 dalam mapel PKn baru mencapai rata-rata skor 5,79 (cukup), dalam mapel IPA baru mencapai rata-rata skor 5,59 (cukup) sedangkan dalam mapel Seni
Budaya mencapai skor rata-rata 5,33 (cukup,). Hal tersebut menunjukkan bahwa aktivitas siswa belum mencapai katagori baik sehingga perlu ditingkatkan.

Berdasarkan hal tersebut, kegiatan yang masih perlu mendapat perhatian khusus dalam PTS ini pada siklus berikutnya adalah peningkatan keterampilan guru terutama dalam kaitannya dengan pemilihan metode dan media pembelajaran yang sesuai dengan pendekatan pembelajaran SERU. Hal ini sesuai dengan prinsip pembelajaran SERU bahwa proses pembelajaran harus mengedapankan keterlibatan siswa yang pelaksanaan diwujudkan dengan penerapan metode dan media pembelajaran yang variatif dan inovatif.

\section{Pembahasan Data Siklus 2}

Berdasarkan hasil refleksi pada siklus 1, pada siklus 2 ini PTS lebih memfokuskan pada peningkatan keterampikan guru dalam penerapan PAKEM, terutama dalam penggunaan metode dan media pembelajaran yang mampu meningkatkan keaktifan siswa dalam kegiatan belajar mengajar. Hasil analisis siklus 2 menunjukkan bahwa:

a. Dilihat dari segi guru, tampak bahwa pada siklus 2 ini keterampilan guru dalam penerapan pendekatan pembelajaran SERU sudah mulai mengalami peningkatan terutama dalam kaitannya dengan pemilihan dan penggunaan metode pembelajaran. Namun, dalam hal pemilihan media terlihat masih kurang variatif dan kurang dapat merangsang aktivitas siswa. Data hasil penilaian RPP pada siklus 2 menunjukkan bahwa pencapaian skor nilai RPP mapel PKn adalah 31 (baik); mapel IPA: 26 (kurang baik) dan dalam mapel Seni Budaya: 28 (kurang baik). Sedangkan berdasarkan data hasil observasi pelaksanaan KBM menunjukkan pencapaian nilai pelaksanaan pembelajaran mapel PKn pada siklus 2 adalah 77 (Baik); mapel IPA mencapai skor 69 (Baik) dan mapel Seni Budaya mencapai skor 70 (Baik). Dengan demikian sekalipun terdapat skor nilai yang dikatagorikan kurang baik, namun bila dilihat skor perolehannya sudah ada peningkatan dibandingkan siklus sebelumnya.

b. Dilihat dari dari segi siswa terlihat adanya peningkatan parrtisipasi siswa dalam kegiatan belajar mengajar. Data hasil observasi menunjukkan bahwa aktivitas siswa dalam kelas 1mencapai rata-rata skor 5,79 (cukup), dalam kelas 2 mencapai (cukup). Kelas 3 mencapai skor rata-rata 7,12 (baik), kelas 4 mencapai 7,30 (baik), dan kelas 5 mencapai 7,44 (Baik). Hal tersebut menunjukkan bahwa aktivitas siswa telah mengalami peningkatan namun belum mencapai katagori baik sehingga perlu ditingkatkan.

Berdasarkan hal tersebut, kegiatan yang masih perlu mendapat perhatian khusus dalam PTS ini pada siklus berikutnya adalah peningkatan keterampilan guru dalam kaitannya dengan pemilihan media pembelajaran yang sesuai dengan pendekatan pembelajaran SERU seperti kasus, cerita, film/video, foto (analisis kasus) dan sebagainya disesuaikan dengan konteks materi yang diajarkan. 
Berdasarakan uraian di atas tampak bahwa hipotesis tindakan dalam PTS menyatakan Penerapan Pendekatan Pembelajaran Senang, Efektif, Ramah dan Unik (SERU) dalam KBM di SDN 84 dapat berjalan efektif.

\section{Kesimpulan}

\section{KESIMPULAN DAN SARAN}

Berdasarkan uraian hasil penelitian dan pembahasan mengenai peningkatan kemampuan guru melaksanakan pendekatan Pembelajaran SERU (Senang, Efektif, Ramah, Unik) melalui tindak lanjut supervisi kunjungan kelas oleh kepala sekolah dapat disimpulkan:

1. Kegiatan bimbingan penerapan Pembelajaran SERU bagi guru SDN 84 Singkawang yang dilaksanakan kepala SDN 84 Singkawang telah terlaksana dengan baik dan memberi kontribusi terhadap peningkatan pemahaman serta keterampilan guru tentang penerapan pendekatan Pembelajaran SERU dalam kegiatan belajar mengajar.

2. Pelaksanaan tindak lanjut supervisi kunjungan kelas dapat m,eningkatkan kemampuan guru dalam melaksanakan pendekatan pembelajaran SERU dalam pengelolaan pembelajaran di SDN 84 Singkawang.

3. Hasil analisis menunjukkan bahwa peningkatan pemahaman dan keterampilan guru tentang penerapan Pembelajaran SERU dalam kegiatan belajar mengajar, berimplikasi pada peningkatan partisipasi atau keaktifan siswa serta terhadap keterlaksanaan nilainilai pembangunan karakter bangsa. Seperti nilai displin, bersih, takwa dan sebagainya.

Saran

Adapun saran yang dapat penulis sampaikan dari penulisan karya ilmiah ini adalah:

1. Penerapan pendekatan Pembelajaran SERU ( Senang, Efektif,Ramah, dan Unik) perlu terus ditingkatkan mengingat cukup signifikan dampak postitif penerapannya terhadap peningkatan proses dan hasil belajar siswa serta bagi terlaksananya nilai-nilai pembangunan karakter bangsa.

2. Guru-guru harus dapat mengenali dan menggunakan berbagai metode, strategi, dan/atau model pembelajaran, sehingga mempunyai banyak pilihan untuk dapat menerapkan pendekatan PAKEM dalam kegaiatan belajar mengajar.

3. Selain keterampilan memilih model pembelajaran, guru yang profesional juga hendaknya dapat memilih media yang tepat untuk menyampaikan materi pembelajaran. Oleh karena itu, guru juga dituntut memliki kreativitas dan keterampilan memilih media pembelajaran yang tepat.

Penguatan pendidikan karakter bangsa merupakan kegiatan yang harus terus di laksanakan terutama di lingkungan sekolah. Oleh karena itu, perlu terus digali model implikasi pembangunan karakter bangsa di sekolah baik secara terintergasi melalui pembelajaran maupun melalui model lainnya.

\section{DAFTAR PUSTAKA}

[1] Hendriana, Evinna Cinda. (2018). Pengaruh Keterampilan Guru dalam Mengelola Kelas terhadap Hasil Belajar Peserta Didik di Sekolah Dasar. JPDI STKIP Singkawang Vol 3 No 2 hal 46-49.

[2] Sunhaji. (2009). Strategi Pembelajaran, Konsep Dasar, Metode, dan Aplikasi. Yogyakarta: Grafindo Litera Media.

[3] Tan, Novita, dkk. (2013). Sekolah Harmoni Hijau halaman 29. Wahana Visi Indonesia.

[4] Sagala, Syaiful. (2010). Supervisi Pembelajaran dalam Profesi Pendidikan. Bandung: Alfabeta.

[5] Mantja, Willem. (2007). Profesionalisasi Tenaga Kependidikan: Manajemen Pendidikan dan Supervisi Pengajaran. Malang: Elang Mas.

[6] Mulyasa. (2006). Menjadi Guru Profesional Menciptakan Pembelajaran Kreatif dan Menyenangkan. Bandung: PT Remaja Rosdakarya.

[7] Purwanto. (2013). Evaluasi Hasil Belajar. Yogyakarta: Pustaka Pelajar.

[8] Arikunto, Suharsimi. (2008). Penelitian Tindakan Kelas. Bandung: Bumi Aksara.

[9] Wiriaatmadja, Rochiati. (2005). Metode Penelitian Tindakan Kelas. Bandung: PT Remaja Rosda. 